\title{
PHYSIOLOGICAL RESPONSES OF COFFEE TREE UNDER DIFFERENT IRRIGATION LEVELS
}

\author{
Jéfferson de O. Costa ${ }^{1 *}$, Rubens D. Coelho², Timóteo H. da S. Barros ${ }^{2}$, \\ Eusímio F. Fraga Júnior ${ }^{3}$, André L. T. Fernandes ${ }^{4}$
}

${ }^{1 *}$ Corresponding author. University of São Paulo/ Piracicaba - SP, Brazil. E-mail: costajo@usp.br

\section{KEYWORDS}

Coffea arabica, leaf temperature, water potential.

\begin{abstract}
The plant water potential and the leaf temperature are physiological responses of the coffee tree that can be used as indicative of the irrigation management of this crop. There is a dependence between the leaf water potential with the potential matrix of the soil solution, however, the water potential levels found for the coffee tree show divergent relationships in the literature regarding the matrix potential. The objective of this study is to verify the water potential and leaf surface temperature in the coffee tree when submitted to different irrigation levels. The study was conducted in Piracicaba, SP, Brazil, using Coffea arabica species from Red Catuaí IAC 144 variety, the drip irrigation system was adopted and the management done by tensiometry. The relationships among these physiological responses and the treatments of actions presented high determination coefficients ( $\mathrm{R}^{2}$ of $0.84,0.90$ and 0.65 for the leaf water potential, leaf temperature measured with the portable infrared sensor and the thermal camera respectively). The estimated values for leaf water potential were $-0.23,-0.56,-0.89$ and $-1.22 \mathrm{MPa}$ for irrigation treatments $\mathrm{L} 130 \%, \mathrm{~L} 100 \%, \mathrm{~L} 70 \%$ and $\mathrm{L} 40 \%$, respectively. The calculated leaf temperature values were $31.7,32.4,33.0$ and $33.7^{\circ} \mathrm{C}$ in average, for treatments $\mathrm{L} 130 \%$, $\mathrm{L} 100 \%, \mathrm{~L} 70 \%$ and $\mathrm{L} 40 \%$ in proper order.
\end{abstract}

\section{INTRODUCTION}

The coffee (Coffea arabica L. and Coffea canephora L.) is a crop of recognized economic importance for Brazil, due to its representativeness as the largest producer, largest exporter and second largest consumer of the grain. In 2016, Brazilian production was 51.4 million bags benefited and the exports reached 34 million bags (FNP Consultoria e comércio, 2017).

As for the physiological processes, coffee is influenced by several environmental factors such as water supply, air temperature and irradiance levels, which influence flowering, fruit development and productivity. The dominant factor in the vegetative and reproductive cycles of coffee, however, is quite variable and depends on the place of cultivation and management practices, among which the most important is irrigation (Silva et al., 2009).

Several studies have verified that there is a dependence between the leaf water potential of the coffee tree and the soil matrix potential in different irrigation managements, however, the water potential levels found are divergent because they work in distinct and uncontrolled environments (Soares et al., 2005; Oliveira et al., 2009; Ronchi et al., 2015; Craparo et al., 2017).

As for leaf temperature, under the same environmental conditions, a plant under water stress conditions presents higher temperature values when compared to cultivated under full conditions of water availability (Testi et al., 2008; Costa et al., 2013).

The use of infrared thermometry as indicative of the leaf water potential has already been studied for several crops such as: bean (Asemanrafat \& Honar, 2017), eggplant (Çolak et al., 2015), citrus (Gonzalez-Dugo et al., 2014), coffee (Craparo et al., 2017), grape (Bellvert et al., 2014), cotton (Cohen et al., 2015), tomato (Ramírez et al., 2015; Silva et al., 2018) and others.

The objective of this study was to verify the physiological responses of the coffee tree in a controlled environment, regarding the water potential and leaf surface temperature, when submitted to different irrigation levels.

\footnotetext{
${ }^{2}$ University of São Paulo/ Piracicaba - SP, Brazil.

${ }^{3}$ Federal University of Uberlândia/ Monte Carmelo - MG, Brazil.

${ }^{4}$ University of Uberaba/ Uberaba - MG, Brazil.

Received in: 3-7-2018

Accepted in: 6-18-2018
} 


\section{MATERIAL AND METHODS}

The experiment was carried out in a protected environment (with control of the plants water supply) located in the research area of the Department of Biosystems Engineering (LEB) at the University of São Paulo (USP/ESALQ), located in Piracicaba municipality, in the state of São Paulo. The geographical coordinates of the experimental area are: $22^{\circ} 42^{\prime} 45^{\prime \prime}$ south latitude and $47^{\circ} 37^{\prime}$ 54" west longitude. The local elevation is approximately 543 meters. The climate of the region, according to the classification of Köppen, is of type Cwa, that is, dry winter and temperature of the hottest month above $22{ }^{\circ} \mathrm{C}$, average temperature of $21.6{ }^{\circ} \mathrm{C}$ and average annual rainfall of $1280 \mathrm{~mm}$.

The greenhouse had a total area of $160 \mathrm{~m}^{2}$ and $3 \mathrm{~m}$ height of the wall until its covering, with transparent polyethylene film covering 150 microns and closed sides with a "sombrite" type screen with $30 \%$ interception. The structure was provided with 56 boxes of 500L $(0.92 \mathrm{~m}$ wide, $1.08 \mathrm{~m}$ long and $0.65 \mathrm{~m}$ high) and at the bottom of them a layer of $5 \mathrm{~cm}$ thick gravel coated with a "Bidim" geotextile blanket was placed. The soil used inside the boxes is classified as Eutrophic Red Nitosol (53\% clay, $16 \%$ silt and $31 \%$ sand), clay phase, called "Luiz de Queiroz Series".
We adopted the drip irrigation system, using dripping tube with self-compensating emitter. Each box had two drippers with an output of $8 \mathrm{~L} \mathrm{~h}^{-1}$. This flow was divided into four points of the box by mini-cuttings. The system was pressurized by a KSB motor pump with engine power of $0.5 \mathrm{hp}$ and the water reservoir used had a capacity of $5 \mathrm{~m}^{3}$. Uniformity tests were performed at the beginning of each evaluation period in order to minimize the effects of poor water distribution on treatments. We used the Uniformity Coefficient of Christiansen (UCC) and the Uniformity of Distribution Coefficient (UDC), obtaining uniformities means of $97.4 \%$ and $94.8 \%$.

For the physical-water characterization of the soil, non-disturbed samples were collected at the beginning of the study. For this, an undisturbed sample was used with $50 \mathrm{~cm}^{3}$ stainless steel cylinders. The samples were collected at three depths, 10,30 and $50 \mathrm{~cm}$, representing the layers $0-20,20-40$ and $40-60 \mathrm{~cm}$, respectively. The determination of the water retention curves in the soil (Figure 1) was done through a tensile table and "Richards" extractors with porous plates (for tensions of 10, 30, 50, 100, 500, 1000 and $1500 \mathrm{kPa}$ ). The physical-water characteristics of the soil determined from the laboratory analyzes can be seen in Table 1 .

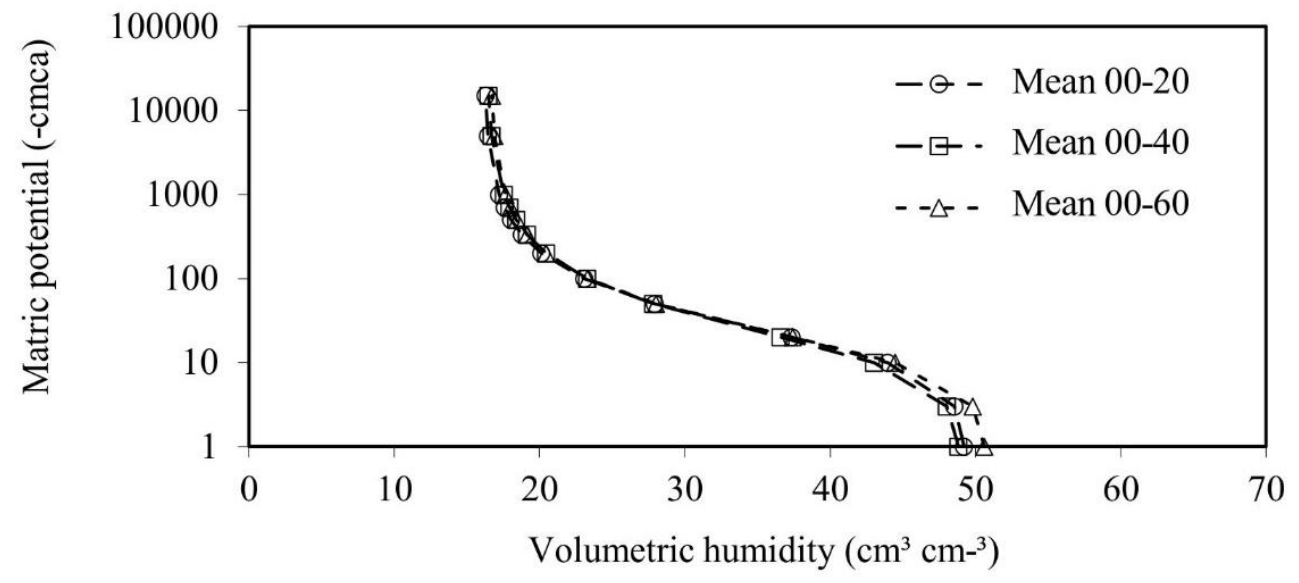

FIGURE 1. Water retention curves in the soil at layers 0-20, 20-40 and 40-60 cm (Average of volumetric moisture in the field capacity and permanent wilting point of 43 and $17 \%$, respectively).

TABLE 1. Physical-water characterization of the soil used in the experiment.

\begin{tabular}{|c|c|c|c|c|c|c|c|c|c|}
\hline Layer & $\theta_{\mathrm{Fc}}$ & $\theta_{\text {pwp }}$ & AWC & Ds & $\mathrm{Dp}$ & $\mathrm{TP}$ & \multicolumn{3}{|c|}{ Granulometric fractions (\%) } \\
\hline $\mathrm{cm}$ & \multicolumn{2}{|c|}{$\mathrm{cm}^{3} \mathrm{~cm}^{-3}$} & $\mathrm{~mm}$ & \multicolumn{2}{|c|}{$\mathrm{g} \mathrm{cm}^{-3}$} & $\%$ & Clay & Silt & Sand \\
\hline $0-20$ & 0.321 & 0.205 & 23.2 & 1.28 & 2.70 & 52.6 & 31.3 & 14.8 & 53.9 \\
\hline $20-40$ & 0.333 & 0.207 & 25.2 & 1.27 & 2.70 & 53.0 & 31.0 & 16.1 & 52.9 \\
\hline $40-60$ & 0.340 & 0.218 & 24.4 & 1.31 & 2.71 & 51.7 & 30.1 & 17.3 & 52.6 \\
\hline
\end{tabular}

$\theta_{\mathrm{Fc}}:$ volumetric soil moisture at field capacity $(-4.85 \mathrm{kPa}) ; \theta_{\mathrm{pwp}}$ : volumetric soil moisture at permanent wilting point $(-1500 \mathrm{kPa})$. AWC: total available water per $20 \mathrm{~cm}$ of soil depth. Ds: soil density; Dp: particle density of the soil; TP: Total soil porosity. 
The irrigation management was carried out by soil, aiming at recovering the volume of water consumed by the plant, as a function of soil water tension data (tensiometry), measured in 12 tensiometers installed in three layers $(20 \mathrm{~cm}, 40 \mathrm{~cm}$ and $60 \mathrm{~cm})$ and four boxes. The soil water tension readings were made with a digital puncture tensimeter calibrated against a mercury column manometer. The interval between the readings was of three days, collecting the data from 7 to 8 o'clock, when the variation in the data is smaller. To perform the calculations of irrigation management, a spreadsheet set up in Microsoft Excel ${ }^{\circledR}$ software was used.

We used a randomized complete block design. It was formed by four blocks and four irrigation levels applied at four different periods, according to Table 2. The experimental unit was represented by a box with plant (spaced $50 \mathrm{~cm}$ between boxes).

TABLE 2. Characterization of different treatment periods.

\begin{tabular}{cccccc}
\hline Periods & Period understood* & $\begin{array}{c}\text { Average temperature } \\
\left({ }^{\circ} \mathrm{C}\right)\end{array}$ & $\begin{array}{c}\text { Solar radiation } \\
\left(\mathrm{MJ} \mathrm{m}^{-2} \text { day }^{-1}\right)\end{array}$ & $\begin{array}{c}\text { Average relative } \\
\text { humidity }(\%)\end{array}$ & $\begin{array}{c}\text { ET } \mathrm{P}_{\mathrm{P}} \text { P56 } \\
\left(\mathrm{mm} \mathrm{day}^{-1}\right)\end{array}$ \\
\hline Period 1 & 03/30 to 04/24 & 24.84 & 12.87 & 77.95 & 2.85 \\
Period 2 & 06/07 to 07/02 & 20.19 & 9.65 & 77.51 & 1.86 \\
Period 3 & 08/17 to 09/11 & 21.73 & 10.27 & 72.46 & 2.31 \\
Period 4 & 10/10 to 11/04 & 26.48 & 12.60 & 71.85 & 3.14 \\
\hline
\end{tabular}

*all evaluations were carried out throughout the year 2015. ETo PM56: reference evapotranspiration by the Penman-Monteith method, as recommended by FAO (Bulletin 56).

The irrigation levels applied were: L130 - 130\% irrigation level, L100 - 100\% irrigation level, L70 - 70\% irrigation level and L40 - 40\% irrigation level. The reference level (L100) kept the soil moisture close to the field capacity $\left(\theta_{\mathrm{Fc}}\right)$ throughout the experiment, which corresponds to the $100 \% \mathrm{ET}_{\mathrm{c}}$ replacement. The other irrigation levels (L40, L70 and L130) were variations in the applied fraction taking as reference the treatment L100.

The imposition of these treatments was carried out in a period of duration of 25 days. This treatments application duration was defined from a previous experiment that showed that this time was sufficient to have changes in the plant water potential and at the same time did not compromise the crop (leaf fall) that would be used in future evaluations. The evaluations were carried out on adult plants (3 years old) of Coffea arabica and Catuaí Red IAC 144 variety. After the treatments application, all the plants received full irrigation. In the period prior to the treatments application (0 to 3 years old) the crop was managed receiving total irrigation.

To obtain the leaf water potential, measurements were made using a pressure chamber model 3005 . Three leaves of the 3rd and / or 4th pair of the upper third of all plants were collected before dawn, being collected 6,12 , 18 and 24 days after the treatments imposition, totaling four evaluations in each season. These samples were conditioned and transported in appropriate containers. With the collected data the averages of the leaf water potential of each plant were realized in the determined days of evaluation.

The option to collect leaves of the 3rd and / or 4th pair of the upper third of the coffee tree is due to the fact that these leaves are representative of the water status of the whole plant, not presenting high humidity (new leaves) or very low humidity (old leaves). However, the choice of starting potentials at 6 days after the treatments imposition was due to the fact that the coffee had no significant physiological response before this period of application of the different water stress levels.
To evaluate the leaf temperature, we use the portable infrared sensor (quick TEMP) and the thermal camera (FLIR T640). The use of two equipment to measure leaf temperature was done to compare methodologies in the determination of leaf temperature.

The evaluations using the portable infrared sensor were performed on the leaves of the 3rd and / or 4th pair of plagiotropic branches of the upper third of the plant (leaves representative of the thermal condition of the whole plant), exposed to the sun and with insertion angle, in relation to the similar vertical plane, in three replicates per plant, being carried out on days of clear and near noon (time in which the incident radiation shows little variation).

Four evaluations were performed on the same days and times of imposition (Table 2) in which the water potential assessments were performed on the leaf. From the data collected, the temperature averages were made per plant on each day of evaluation. The leaf temperature measurements with the portable infrared sensor were corrected by multiplying the values collected by the calibration factor of the equipment used, according to [eq. (1)]:

$$
\mathrm{Tc}=1.023 \mathrm{Tm}
$$

Where:

Tc - corrected temperature, ${ }^{\circ} \mathrm{C}$, and

$\mathrm{Tm}$ - measured temperature, ${ }^{\circ} \mathrm{C}$.

The thermal evaluations using the thermal camera were performed at the end of the treatment imposition and in the same four periods (Table 2) of the evaluations using the portable infrared sensor. All plants submitted to treatments were photographed and the images were analyzed in FLIR Tools software. 
The analysis within the program was done by selecting an image area of $100 \times 100$ pixels (approximately $400 \mathrm{~cm}^{2}$ ) from the upper third of the plant, considered a representative portion of the canopy. After selecting this area, the average plant temperature was calculated using the same software based on the temperature values of 10000 pixels. Thus, the temperature averages were made per plant on each day of evaluation.

For the analysis of variance of the results the software Sisvar version 5.4 was used. The variables that presented significant $\mathrm{F}$ values at $5 \%$ probability in the analysis of variance were submitted to regression analysis and the Tukey averages test at $5 \%$ of probability. Data

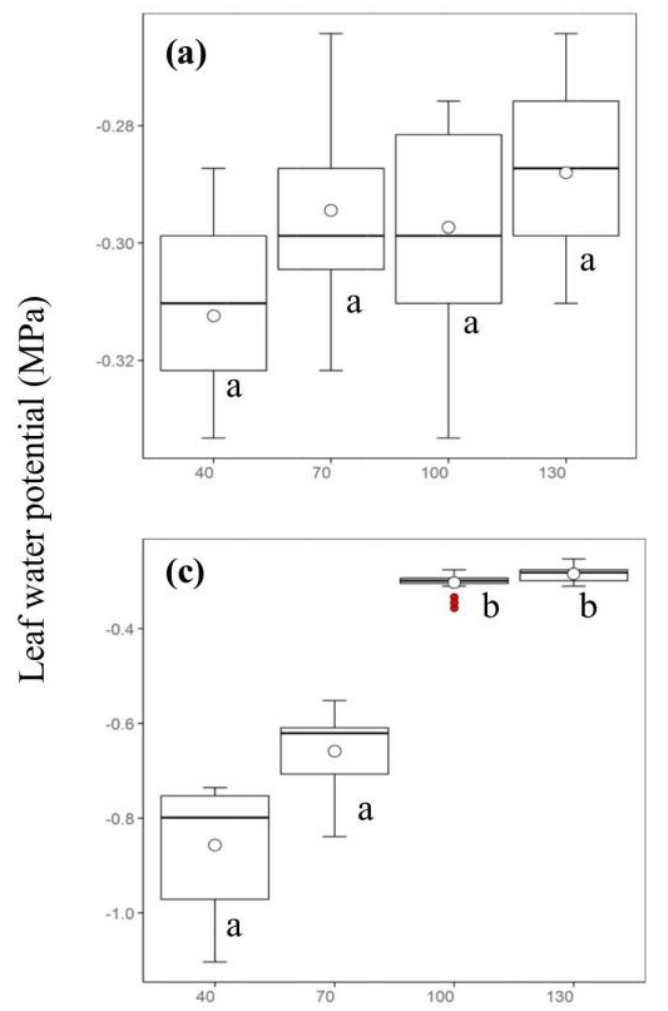

dispersion was also evaluated using box-plot type graphs created in Microsoft Excel ${ }^{\circledR}$ and Action Stat ${ }^{\circledR}$ software.

\section{RESULTS AND DISCUSSION}

In the evaluations made 6 days after the treatments imposition (Figure 2a), it was observed that the variability was similar for all applied depth and that the median value of leaf water potential was around $-0.3 \mathrm{MPa}$ for all treatments. At 12 days after the treatments imposition (Figure 2b), the variability of the data was higher in the treatments L40 and L70\% (treatments with deficit depths), but the median value of leaf water potential continued around $-0.3 \mathrm{MPa}$ for all treatments.
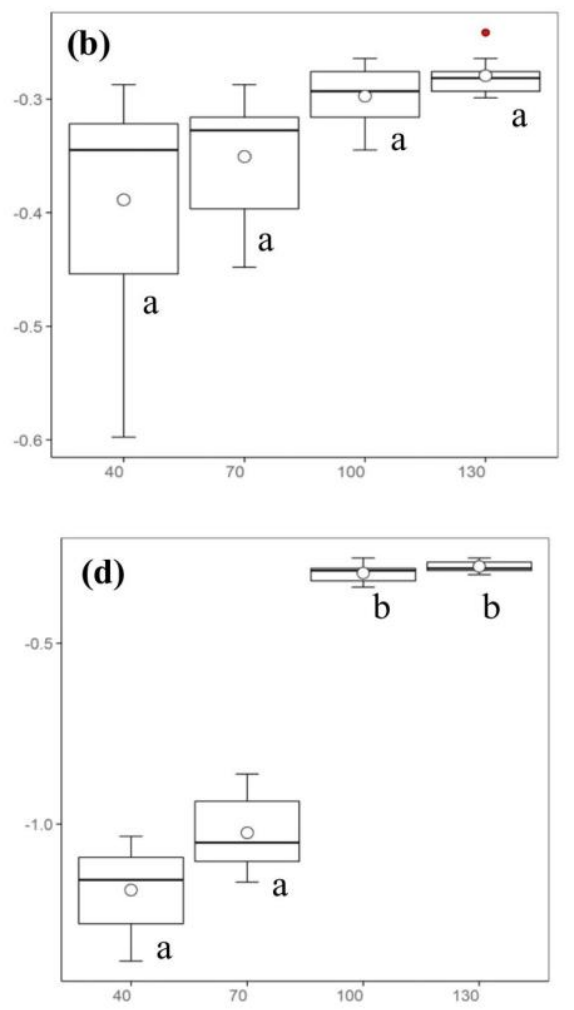

Irrigation levels (\%)

FIGURE 2. Box-plot graphs for leaf water potential values on different irrigation levels measured at 6 days' post treatment imposition (a); 12 days after the treatments imposition (b); 18 days after the treatments imposition (c); 24 days after the treatments imposition (d). Different letters differ from each other at a 5\% probability level by the Tukey test.

With these plants response it is possible to infer that until the 12 days after the treatments imposition the deficit depth did not affect the leaf water potential significantly, under the experiment conditions. Soares et al. (2005) evaluated adult coffee trees with eight years of planting and found leaf water potential differences between irrigated and non-irrigated plants only 30 days after the treatments imposition, and those that received full irrigation presented a leaf water potential of - $0.2 \mathrm{MPa}$.

Ronchi et al. (2015) studied the early water potential of Catuaí Red IAC 144 and Bourbon Yellow J9 cultivars submitted to treatments not irrigated, irrigated continuously and with different periods of irrigation suspension and observed that in the first cultivar the behavior of the evaluated variable was the same for all treatments at 30 days, presenting values around -0.2 $\mathrm{MPa}$. In the Bourbon Amarelo J9 cultivar, the variable behaved differently, presenting values that varied from -0.1 MPa in the treatment irrigated continuously at $-0.8 \mathrm{MPa}$ in the non-irrigated treatment. Possibly, the cultivars presented different rates of water utilization during the treatment imposition period and, consequently, reached different water deficit levels, represented by different leaf water potentials.

In the evaluations at 18 days after the treatments imposition (Figure 2c) the variability of the data was higher in treatments $\mathrm{L} 40 \%$ and $\mathrm{L} 70 \%$ compared to treatments $\mathrm{L} 130 \%$ and $\mathrm{L} 100 \%$. The median value of leaf water potential for the deficit depth was between -0.6 and $0.8 \mathrm{MPa}$. Finally, at 24 days after the treatments imposition (Figure 2D), the variability was also higher in treatments $\mathrm{L} 40 \%$ and $\mathrm{L} 70 \%$, which presented mean values of leaf water potential above -1.0 MPa. 
These data confirm the study of Oliveira et al. (2009) who evaluated the physiological behavior of different coffee cultivars submitted to different water availability in the soil for 30 days and verified that different irrigation management provided different levels of leaf water potential in coffee trees.

From the data of leaf water potential at 24 days after the treatments imposition (moment in which the most evident differences of leaf water potential were verified) a simple linear regression was adjusted to describe the behavior of this variable in function of the different irrigation levels (Figure 3).

The leaf water potential presented a good relation $\left(\mathrm{R}^{2}=0.84\right)$ with the irrigation level applied. This relationship showed an increase in the analyzed variable as the percentages of the irrigation levels increased. Using the linear equation, the estimated values for leaf water potential were calculated as $-0.23,-0.56,-0.89$ and -1.22 $\mathrm{MPa}$ for the treatments $\mathrm{L} 130 \%, \mathrm{~L} 100 \%, \mathrm{~L} 70 \%$ and $\mathrm{L} 40 \%$, respectively.

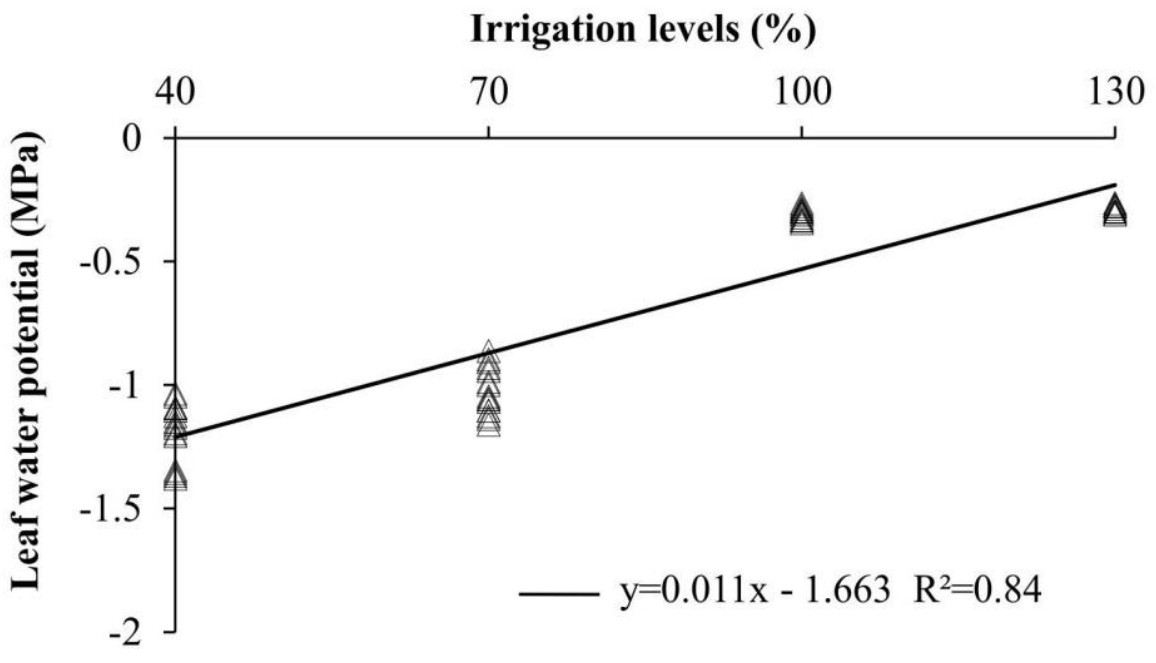

FIGURE 3. Leaf water potential as a function of different irrigation levels.

Soares et al. (2005) observed values of -0.2 and $0.8 \mathrm{MPa}$ for treatments irrigated permanently and not irrigated for thirty days, when studying the effect of water deficit in adult coffee trees in the region of Viçosa-MG. At 60 days after the treatments imposition the leaf water potential of the non-irrigated treatment reached -1.2 $\mathrm{MPa}$ and remained at $-0.2 \mathrm{MPa}$ for the treatment irrigated permanently. At 90 days, the values were -0.2 and -1.8 $\mathrm{MPa}$ for treatments irrigated permanently and not irrigated.

Ronchi et al. (2015) found values of leaf water potential in the Catuaí Red IAC 144 cultivar of -0.10, $0.35,-0.5$ and $-0.6 \mathrm{MPa}$ for treatments irrigated continuously, 30 days of irrigation suspension, 60 days of irrigation suspension and non-irrigated, respectively. The results found by these authors diverge, in parts, from the values estimated by the equation of the suggested line, however, the edaphoclimatic conditions and the crop management in each study affect the rate of water use by the plants, thus altering their water potential.

Figure 4 shows that the variability of the leaf temperature data obtained with the portable infrared sensor the data was similar in all irrigation levels at 6,12, 18 and 24 days after the treatments imposition. In the evaluations made 6 days after the treatments imposition (Figure 4a), it was observed that the median leaf temperature was close to $34^{\circ} \mathrm{C}$ for all treatments. At 12 days after the treatments imposition (Figure 4b) the median leaf temperature was between 34 and $35^{\circ} \mathrm{C}$ for all treatments. 


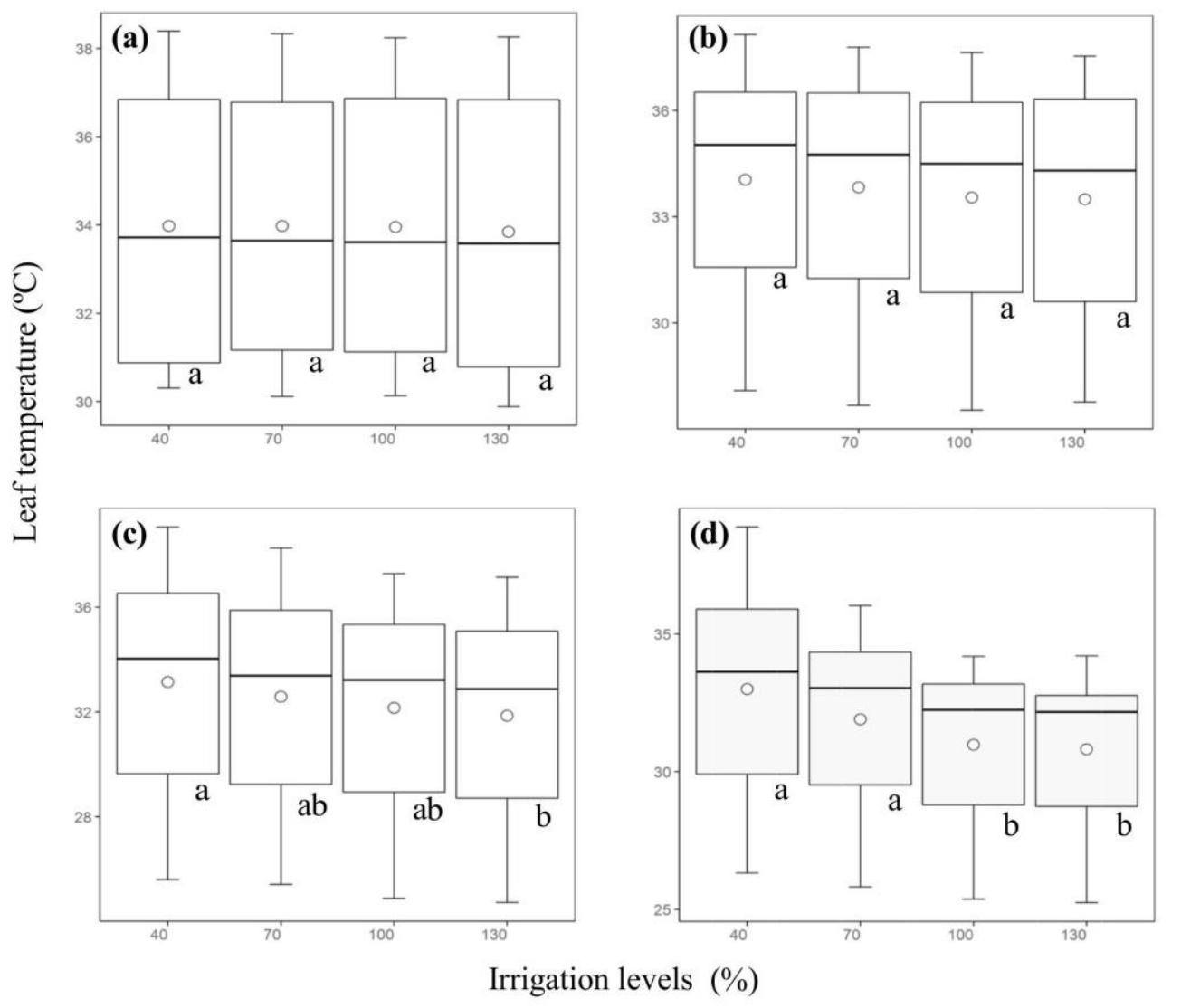

FIGURE 4. Box-plot graphs for leaf temperature values measured with the portable infrared sensor on different irrigation levels at 6 days after the treatments imposition (a); At 12 days after the treatments imposition (b); At 18 days after the treatments imposition (c); To 24 days after the treatments imposition (d). Different letters differ from each other at a 5\% probability level by the Tukey test.

These plants responses allows to affirm that, under the conditions of the experiment, the deficit depth did not allow the occurrence of a significant temperature difference between plants with or without water deficit until 12 days after the treatments imposition. Probably, in this period, the plants submitted to treatments $\mathrm{L} 70 \%$ and L40\% maintained their transpiratory activity at the same level as the others. For this reason, it was not possible to verify a considerable leaf temperature difference between the plants submitted to the treatments $\mathrm{L} 130 \%$ and L100\% and the plants submitted to the treatments with deficit depth.

In the evaluations at 18 days after the treatments imposition (Figure 4c) the median leaf temperature was between 32 and $34^{\circ} \mathrm{C}$ for all treatments. The leaf temperature difference between the $\mathrm{L} 40 \%$ treatment and the $\mathrm{L} 130 \%$ treatment was approximately $1{ }^{\circ} \mathrm{C}$. Finally, at 24 days after the treatments imposition (Figure 4d) the treatments $\mathrm{L} 40 \%$ and $\mathrm{L} 70 \%$ presented mean values of leaf temperature higher than treatments $\mathrm{L} 130 \%$ and L100\%. In treatments with deficit depth the leaf temperature was 1 to $3^{\circ} \mathrm{C}$ higher than the foliar temperature of the treatments $\mathrm{L} 130 \%$ and $\mathrm{L} 100 \%$.

In Figure 5 it can be observed that the variability of the data of leaf temperature measured with the thermal camera differed in the periods and in function of the irrigation levels. In period 1 , the average leaf temperature in the $\mathrm{L} 40 \%$ treatment was approximately $3{ }^{\circ} \mathrm{C}$ higher than the average leaves temperature in the treatments L130\% and $\mathrm{L} 100 \%$. Regarding to the treatment with $\mathrm{L} 70 \%$, this difference was approximately $2.5^{\circ} \mathrm{C}$. At period 2 , the average leaf temperature in the $\mathrm{L} 40 \%$ treatment was approximately $2.5^{\circ} \mathrm{C}$ higher than the average leaves temperature in the treatments $\mathrm{L} 130 \%$ and $\mathrm{L} 100 \%$. Regarding treatment with $\mathrm{L} 70 \%$, this difference was approximately $2^{\circ} \mathrm{C}$.

The lower leaf temperature differences between plants submitted to the different treatments found in period 2 can be explained by the lower incidence of solar radiation and the milder temperatures during this period, which resulted in lower evapotranspiration values. According to Trentin et al. (2011) the temperature difference between the crop and the air is closely linked to the transpiration process, as it increases there is a reduction in leaf temperature due to energy dissipation in the form of latent heat.

In period 3 , the average leaf temperature in the L40\% treatment was approximately $2{ }^{\circ} \mathrm{C}$ higher than the average leaves temperature in the treatments with $\mathrm{L} 130 \%$. In relation to treatments $\mathrm{L} 100 \%$ and $\mathrm{L} 70 \%$, this difference was approximately $1{ }^{\circ} \mathrm{C}$, however, there was no statistical difference between these two treatments. In period 4 , the average leaf temperature in the $\mathrm{L} 40 \%$ treatment was approximately $1^{\circ} \mathrm{C}$ higher than the leaf mean temperature in the $\mathrm{L} 130 \%$ treatments. In relation to treatments $\mathrm{L} 100 \%$ and $\mathrm{L} 70 \%$ this difference was lower than $1{ }^{\circ} \mathrm{C}$. There was no statistical difference between treatments L40\%, L70\% and $\mathrm{L} 100 \%$. 


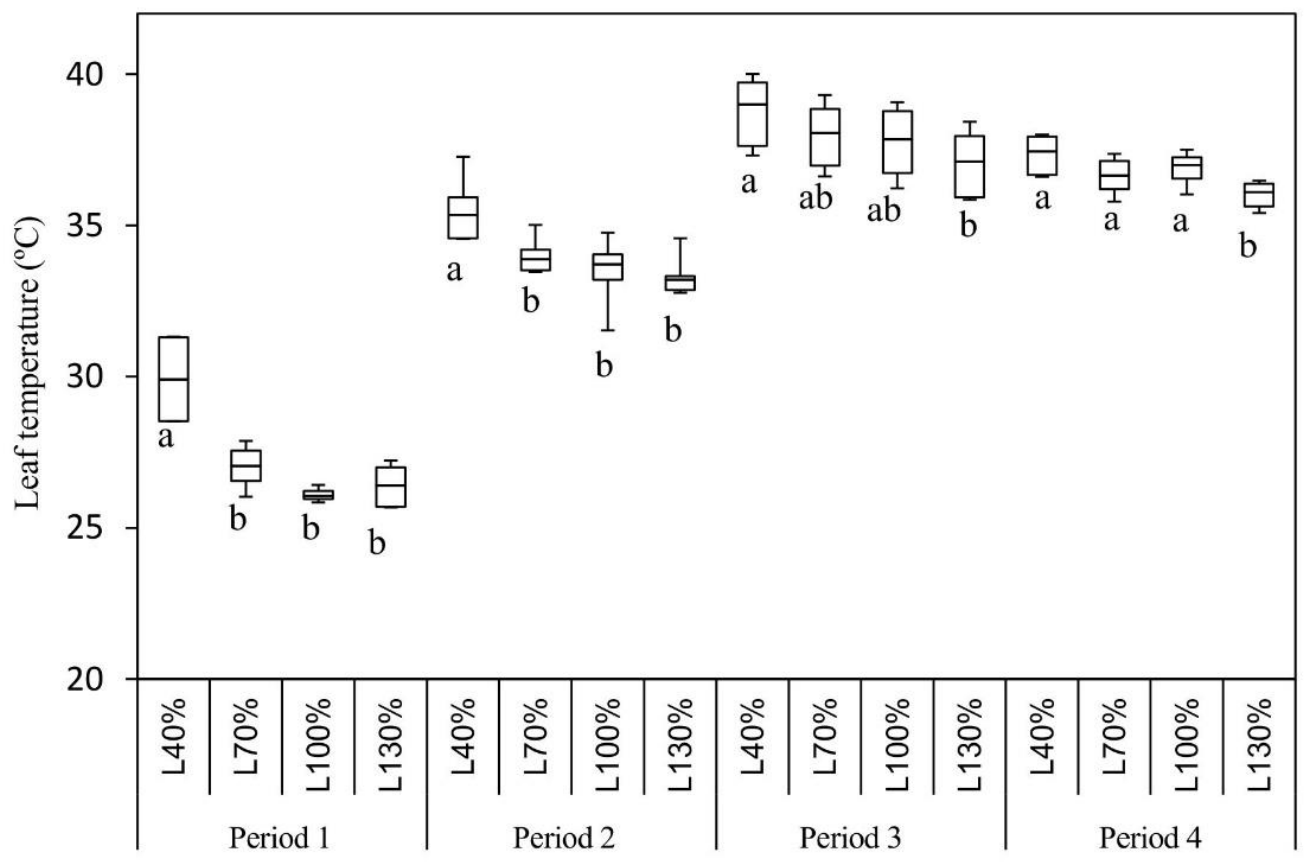

FIGURE 5. Box-plot graph for leaf temperature values measured with the thermal camera in different irrigation levels in the four periods of treatments imposition. Different letters differ from each other at a 5\% probability level by the Tukey test, within each period.

The lowest leaf temperature differences between plants submitted to the different treatments found in periods 3 and 4 can be explained by the defoliation caused by the treatments imposition, 4 months before, in periods 1 and 2. Defoliation damages the thermal image quality, because it begins to express temperatures that are not related to the foliage of the plant. Thus, the temperature means between plants with different treatments are closer since these averages account not only the temperatures of the canopy, but also points in common outside the canopy.

From the data of leaf temperature (portable infrared sensor and thermal camera) measured at the end of the treatments imposition (moment in which the most evident differences were verified) a simple linear regression for each equipment was adjusted in an attempt to describe the behavior of this variable in different irrigation levels (Figure 6).

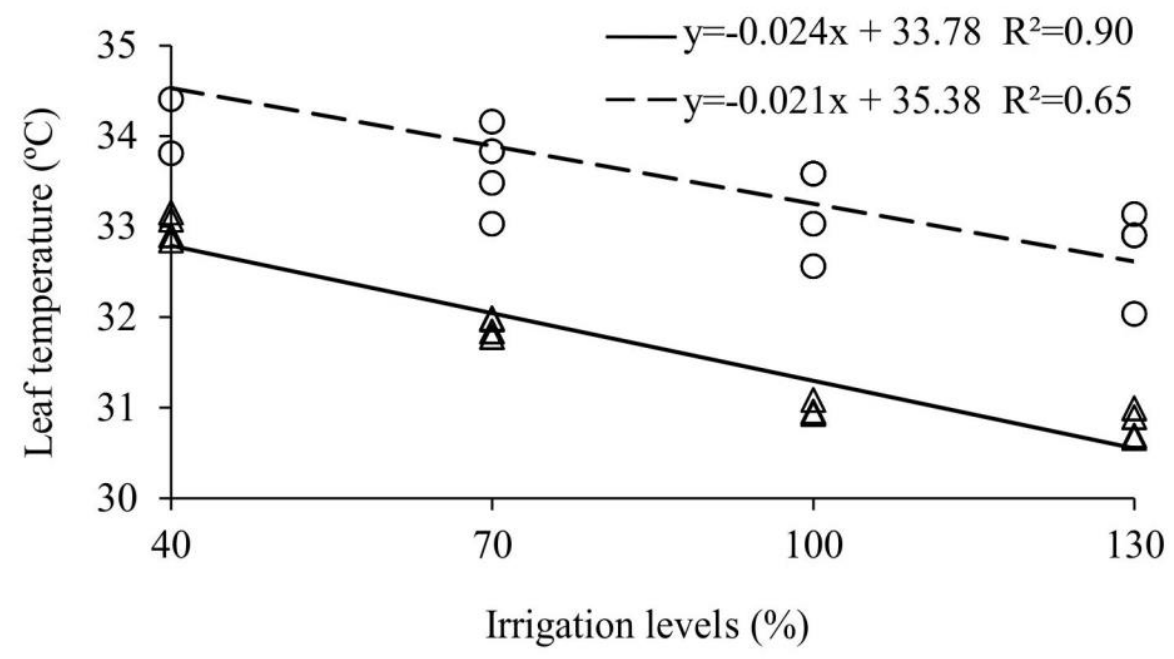

FIGURE 6. Leaf temperature measured with the thermal camera (o) and with the portable infrared sensor $(\Delta)$ as a function of different irrigation levels. 
The leaf temperature measured with the portable infrared sensor $(\Delta)$ presented a good relation $\left(\mathrm{R}^{2}=0.90\right)$ with the irrigation level applied. The leaf temperature measured with the thermal camera (o) presented a not so good relation as that of the portable infrared sensor $\left(\mathrm{R}^{2}=0.65\right)$. The two relationships showed a decrease of the analyzed variable as the percentages of the irrigation levels increased.

Using the linear equation of the portable infrared sensor, leaf temperature values were estimated for the different irrigation levels. The calculated values were 30.7 , $31.4,32.1$ and $32.8^{\circ} \mathrm{C}$ for the treatments $\mathrm{L} 130 \%$, $\mathrm{L} 100 \%$, L70\% and L40\%, respectively. From these values it is possible to affirm that in the conditions of the experiment, the leaf temperature measured with the portable infrared sensor of the plants submitted to deficit depth was approximately $1.5^{\circ} \mathrm{C}$ higher than the leaf temperature of the plants that received the treatments L130 and L100\%.

Trentin et al. (2011), using portable infrared sensor to evaluate the leaf temperature of sugarcane, verified differences between the crop temperature and the temperature of the air that remained around $3.8^{\circ} \mathrm{C}$ in a condition of severe stress and of $1.9^{\circ} \mathrm{C}$. In a condition of moderate stress, that is, the leaf temperature of plants submitted to severe water stress was $1.9^{\circ} \mathrm{C}$ higher than the leaf temperature of plants with moderate stress.

Leaf temperature values were also estimated for the different irrigation levels using the equation of the thermal camera line. The calculated values were $32.7,33.3,33.9$ and $34.5^{\circ} \mathrm{C}$ for the treatments $\mathrm{L} 130 \%, \mathrm{~L} 100 \%, \mathrm{~L} 70 \%$ and L $40 \%$, respectively. From these values it is possible to affirm that under the conditions of the experiment, the leaf temperature measured with the thermal camera of the plants submitted to deficit depth was approximately $1.0^{\circ} \mathrm{C}$ higher than the leaf temperature of the plants that received the treatments $\mathrm{L} 130 \%$ and $\mathrm{L} 100 \%$.

Ramírez et al. (2015) evaluating the tomato leaves using the thermal camera, also verified that the plants submitted to water stress presented differences between leaf temperatures and air temperatures higher than plants without water stress. The maximum values found for temperature differences between plants with and without water stress were $6.71^{\circ} \mathrm{C}$.

\section{CONCLUSIONS}

1. The leaf water potential of the coffee tree and the leaf temperature varied according to the different irrigation levels applied in the treatments. The relationships between these physiological responses and the treatments imposed had high determination coefficients.

2. The estimated values for leaf water potential were $-0.23,-0.56,-0.89$ and $-1.22 \mathrm{MPa}$ for the irrigation levels $\mathrm{L} 130 \%, \mathrm{~L} 100 \%$, L70\% and L40\%, respectively. The calculated values of leaf temperature were 31.7, 32.4, 33.0 and $33.7^{\circ} \mathrm{C}$, on average, for the treatments L130, L100, $\mathrm{L} 70$ and $\mathrm{L} 40 \%$, in proper order.

\section{ACKNOWLEDGMENTS}

This study was financed in part by the Coordenação de Aperfeiçoamento de Pessoal de Nível Superior - Brasil (CAPES) - Finance Code 001. We thank also the National Council for Scientific and Technological Development $(C N P q)$ for their granting of scholarships to students and the co-authors of this work. This experiment was supported by the Brazilian Research Agency Fundação de Amparo à Pesquisa do Estado de São Paulo - FAPESP 2012/50083-7.

\section{REFERENCES}

Asemanrafat M, Honar T (2017) Effect of water stress and plant density on canopy temperature, yield components and protein concentration of red bean (Phaseolus vulgaris L. cv. Akhtar). International Journal of Plant Production 11(2):241-258. DOI: https://doi.org/10.22069/IJPP.2017.3422

Bellvert J, Zarco-Tejada PJ, Girona J, Fereres E (2014) Mapping crop water stress index in a "Pinot-noir" vineyard: comparing ground measurements with thermal remote sensing imagery from an unmanned aerial vehicle. Precision Agriculture 15(4):361-376. DOI: https://doi.org/10.1007/s11119-013-9334-5

Cohen Y, Alchanatis V, Sela E, Saranga Y, Cohen S, Meron M, Bosak A, Tsipris J, Ostrovsky V, Orolov V, Levi A, Brikman R (2015) Crop water status estimation using thermography: multi-year model development using ground-based thermal images. Precision Agriculture 16(3):311-329. DOI: https://doi.org/10.1007/s11119-0149378-1

Çolak YB, Yazar A, Çolak İ, Akça H, Duraktekin G (2015) Evaluation of crop water stress index (CWSI) for eggplant under varying irrigation regimes using surface and subsurface drip systems. Agriculture and agricultural science procedia 4:372-382. DOI:

https://doi.org/10.1016/j.aaspro.2015.03.042

Costa JM, Grant OM, Chaves MM (2013) Thermography to explore plant-environment interactions. Journal of Experimental Botany 64(13):3937-3949. DOI: https://doi.org/10.1093/jxb/ert029

Craparo ACW, Steppe K, Van Asten PJA, Läderach P, Jassogne LTP, Grab SW (2017) Application of thermography for monitoring stomatal conductance of Coffea arabica under different shading systems. Science of the Total Environment 609(12):755-763. DOI: https://doi.org/10.1016/j.scitotenv.2017.07.158

FNP Consultoria e comércio (2017) Agrianual 2017: anuário da agricultura brasileira. São Paulo, 521p.

Gonzalez-Dugo V, Zarco-Tejada PJ, Fereres E (2014) Applicability and limitations of using the crop water stress index as an indicator of water deficits in citrus orchards. Agricultural and forest meteorology 198(12):94-104. DOI: https://doi.org/10.1016/j.agrformet.2014.08.003

Oliveira LFC de, Oliveira RZ, Castro TAP (2009) Comportamento fisiológico de cafeeiros submetidos a diferentes disponibilidades de água no solo. Bioscience Journal 25(3):83-91. 
Ramírez AJF, Coelho RD, Pizani MAM, Silva CJ da (2015) Determinação do índice de estresse hídrico em tomateiros cereja (Lycopersicum solanum var.

cerasiforme.) com câmara infravermelha. Revista Brasileira de Agricultura Irrigada 9(4):218-224. DOI: http://dx.doi.org/10.7127/rbai.v9n400356

Ronchi CP, Araújo FC de, Almeida WL de, Silva MAA da, Magalhães CEO, Oliveira LB de, Drumond LCD (2015) Respostas ecofisiológicas de cafeeiros submetidos ao deficit hídrico para concentração da florada no cerrado de Minas Gerais. Pesquisa Agropecuária Brasileira 50(1):24-32. DOI: http://dx.doi.org/10.1590/S0100204X2015000100003

Silva CJ da, Silva CA da, Freitas CA de, Golynski A, Silva LF da, Frizzone JA (2018) Tomato water stress index as a function of irrigation depths. Revista Brasileira de Engenharia Agrícola e Ambiental 22(2):95-100. DOI: http://dx.doi.org/10.1590/1807-1929/agriambi.v22n2p95100
Silva ED, Brunini O, Sakai E, Arruda FB, Pires RDM (2009) Influência de déficits hídricos controlados na uniformização do florescimento e produção do cafeeiro em três diferentes condições edafoclimáticas do Estado de São Paulo. Bragantia 68(2):493-501.

Soares AR, Mantovani EC, Rena AB, Soares AA (2005) Irrigação e fisiologia da floração em cafeeiros adultos na região da zona da mata de Minas Gerais. Acta Scientiarum Agronomy 27(1):117-125. DOI: http://dx.doi.org/10.4025/actasciagron.v27i1.2128

Testi L, Goldhamer DA, Iniesta F, Salinas M (2008) Crop water stress index is a sensitive water stress indicator in pistachio trees. Irrigation Science 26(5):395-405. DOI: https://doi.org/10.1007/s00271-008-0104-5

Trentin R, Zolnier S, Aristides R, Steidle Neto AJ (2011) Transpiração e temperatura foliar da cana-de-açúcar sob diferentes valores de potencial matricial. Engenharia Agrícola 31(6):1085-1095. DOI:

https://doi.org/10.1590/S0100-69162011000600006 